\title{
Virtual memory cells make a major contribution to the response of aged influenza-naïve mice to influenza virus infection
}

\author{
Kathleen G. Lanzer, Tres Cookenham, William W. Reiley and Marcia A. Blackman*
}

\begin{abstract}
Background: A diverse repertoire of naïve T cells is thought to be essential for a robust response to new infections. However, a key aspect of aging of the T cell compartment is a decline in numbers and diversity of peripheral naive $T$ cells. We have hypothesized that the age-related decline in naïve $T$ cells forces the immune system to respond to new infections using cross-reactive memory $T$ cells generated to previous infections that dominate the aged peripheral T cell repertoire.

Results: Here we confirm that the CD8 T cell response of aged, influenza-naïve mice to primary infection with influenza virus is dominated by $T$ cells that derive from the memory $T$ cell pool. These cells exhibit the phenotypic characteristics of virtual memory cells rather than true memory cells. Furthermore, we find that the repertoire of responding CD8 T cells is constrained compared with that of young mice, and differs significantly between individual aged mice. After infection, these virtual memory CD8 T cells effectively develop into granzyme-producing effector cells, and clear virus with kinetics comparable to naïve CD8 T cells from young mice.

Conclusions: The response of aged, influenza-naive mice to a new influenza infection is mediated largely by memory CD8 T cells. However, unexpectedly, they have the phenotype of VM cells. In response to de novo influenza virus infection, the VM cells develop into granzyme-producing effector cells and clear virus with comparable kinetics to young CD8 T cells.
\end{abstract}

Keywords: T cell receptor repertoire, Virtual memory (VM) T cells, True memory (TM) T cells, Influenza, Ageing, Mouse model

\section{Background}

A diverse repertoire of naïve $T$ cells is thought to be necessary for an optimal response to infections [1-6]. With age, the numbers of naïve $\mathrm{T}$ cells decline, such that the ratio of memory-phenotype to naïve $\mathrm{T}$ cells in the periphery greatly increases. In addition, the repertoire diversity becomes constrained [7-15]. The decline of the naïve repertoire of $\mathrm{CD} 8 \mathrm{~T}$ cells with age is a consequence of reduced thymic output, increasing antigen experience, peripheral homeostatic proliferation and the development of large clonal expansions of cells displaying a memory phenotype [16-21].

\footnotetext{
* Correspondence: mblackman@trudeauinstitute.org

Trudeau Institute, 154 Algonquin Avenue, Saranac Lake, NY 12983, USA
}

The decline in naïve $\mathrm{T}$ cells with aging has been correlated with impaired immunity and reduced ability to respond to new infections [3-6, 13, 22, 23]. Consistent with this, our previous studies confirmed that declining numbers of naive CD8 $\mathrm{T}$ cells in aged mice correlated with poor responses to de novo infection with influenza virus [7]. Specifically, the response to an immunodominant nucleoprotein epitope $\left(\mathrm{NP}_{366}\right)$, but not the co-dominant epitope $\left(\mathrm{PA}_{224}\right)$, was found to be dramatically reduced in aged mice. We further showed that the naïve precursor frequency of NP-specific CD8 T cells was 10-fold lower than PA-specific CD8 $\mathrm{T}$ cells in aged mice, providing an explanation for the selective decline in the immune response to influenza virus NP. This study provided proof of

(C) The Author(s). 2018 Open Access This article is distributed under the terms of the Creative Commons Attribution 4.0 International License (http://creativecommons.org/licenses/by/4.0/), which permits unrestricted use, distribution, and 
concept that the naïve repertoire to epitopes with a low precursor frequency may become so constrained during aging that "holes" develop in the repertoire [7].

With increasing antigen experience during the lifespan and the decline in numbers and diversity of naïve $\mathrm{T}$ cells, we have hypothesized that memory CD8 $\mathrm{T}$ cells generated in response to previous antigen exposure and that are fortuitously cross reactive make a major contribution to $\mathrm{T}$ cell responses to de novo infections in aged mice [6]. Consistent with this hypothesis, unexpected cross-reactivity has been demonstrated between CD8 T cells specific for distinct epitopes expressed by different viruses [24-31]. It has also been shown that CD4 T cells respond to antigens to which the individual has never been exposed, as a consequence of cross-reactivity [32]. Together, the data show that $\mathrm{T}$ cell recognition of antigen/MHC is highly degenerate, and $\mathrm{T}$ cell responses exhibit extensive and unexpected cross reactivity $[5,33]$.

Fortuitously cross-reactive memory CD8 T cells provide a potential explanation of how protection can be maintained within aged mice as the naïve repertoire declines. One prediction of this hypothesis is that the CD8 $T$ cell response to new infections in aged mice would be likely to exhibit reduced repertoire diversity compared to CD8 $\mathrm{T}$ cell responses in young mice. In addition, the specific and perhaps unique prior antigenic experience and repertoire of memory cells in each individual would result in heterogeneous responses in individual aged animals. Another prediction of the hypothesis is that the reduced repertoire diversity of the fortuitously cross reactive memory $\mathrm{T}$ cell responses would result in impaired immunity and delayed viral clearance in aged mice [6]. The goal of the current study was to test these possibilities.

Conventional memory CD8 $\mathrm{T}$ cells can be classified into three distinct types that are distinguished by phenotypic markers and trafficking patterns. One population, effector memory cells (EM), express low levels of CD62L and CCR7, lack the ability to home to lymph nodes, and preferentially localize to peripheral tissues. A second population, central memory cells $(\mathrm{CM})$, express high levels of CD62L and CCR7, and circulate through the blood and secondary lymphoid organs. A third population, resident memory cells $\left(\mathrm{T}_{\mathrm{RM}}\right)$, express CD69 and CD103, reside in the peripheral tissues, and do not circulate [34-37].

Memory cells were originally defined as a population of long-lasting cells generated by exposure to antigen. However, recently it has become apparent that antigen-specific, memory-phenotype $\mathrm{T}$ cells can also develop in the absence of antigenic stimulation. For example, antigen-specific memory phenotype $\mathrm{T}$ cells can be detected by antigen/MHC tetramers from naive and germ-free mice. In one study, CD8 $\mathrm{T}$ cells specific for three different peptides from ovalbumin, vaccinia virus and herpes simplex virus were isolated from naïve mice and, unexpectedly, a significant percentage of the cells were of a memory phenotype (CD44 $\left.4^{\text {High }}\right)$ [38]. There are two major subsets of these antigen-inexperienced memory cells, termed innate memory and virtual memory (VM) [39]. These subsets are difficult to distinguish phenotypically, as both populations of antigen-inexperienced memory cells are characterized by their high expression of CD62L and CD122, and low expression of CD49d. However, there are developmental and functional differences between the two subsets of cells [39]. Importantly for this study, there are relatively few innate memory cells in C57BL/6 mice $[39,40]$, and the frequency of VM cells have been shown to increase with age, such that the majority of CD8 $\mathrm{T}$ cells in aged C57BL/6 mice, used in this study, have a VM phenotype $[2,41,42]$. These data raise the possibility that VM cells contribute to the response of aged, influenza-naïve mice to de novo influenza infection.

In this study we have tested the hypothesis that cross-reactive memory $\mathrm{T}$ cells not specifically elicited by previous infection play a major role in the response of aged mice to new infections. As predicted, we show that the response of aged, influenza-naive mice to a new influenza infection is mediated largely by memory CD8 T cells that exhibit reduced repertoire diversity that is heterogeneous in individual mice. However, unexpectedly, they have the phenotype of VM cells. In response to de novo influenza virus infection, the VM cells develop into granzyme-producing effector cells and clear virus with comparable kinetics to young CD8 T cells.

\section{Results}

Memory CD8 T cells from aged, influenza-naïve mice respond to de novo infection with influenza virus and produce only minimal responses to influenza NP

To demonstrate that memory CD8 $\mathrm{T}$ cells from aged mice that had not previously been exposed to influenza virus were capable of responding to influenza virus, we FACS-sorted memory CD8 T cells (CD44 ${ }^{\text {High }}$ ) from aged, naïve specific pathogen free mice and adoptively transferred them into young $\mathrm{T}$ cell-deficient (TCR $\beta \delta-/-$ ) mice. The following day the mice were infected with influenza virus and on day 12 post infection (p.i.) the responding CD8 T cells were tested for reactivity to a panel of five MHC class I influenza-specific epitopes from the viral proteins - nucleoprotein $\left(\mathrm{NP}_{366} / \mathrm{D}^{\mathrm{b}}\right)$, acid polymerase $\left(\mathrm{PA}_{224} / \mathrm{D}^{\mathrm{b}}\right)$, basic polymerase I $\left(\mathrm{PB}_{703} / \mathrm{K}^{\mathrm{b}}\right)$, the $\mathrm{F} 2$ of $\mathrm{PB} 1$ $\left(\mathrm{PB} 1 \mathrm{~F} 2_{62} / \mathrm{D}^{\mathrm{b}}\right)$ and non-structural protein $2\left(\mathrm{NS} 2_{114} / \mathrm{K}^{\mathrm{b}}\right)$ Fig. 1a. It has previously been shown in young mice that the antigen-specific $\mathrm{T}$ cell response to the $\mathrm{NP}_{366} / \mathrm{D}^{\mathrm{b}}$ and the $\mathrm{PA}_{224} / \mathrm{D}^{\mathrm{b}}$ epitopes are relatively equi-dominant following primary infection with influenza virus (see a representative control response in Fig. 1b), whereas the secondary antigen-specific $\mathrm{T}$ cell response is sharply biased toward the $\mathrm{NP}_{366} / \mathrm{D}^{\mathrm{b}}$ epitope [43-45]. In contrast, we have demonstrated a dramatically reduced response to $\mathrm{NP}_{366} / \mathrm{D}^{\mathrm{b}}$ in 

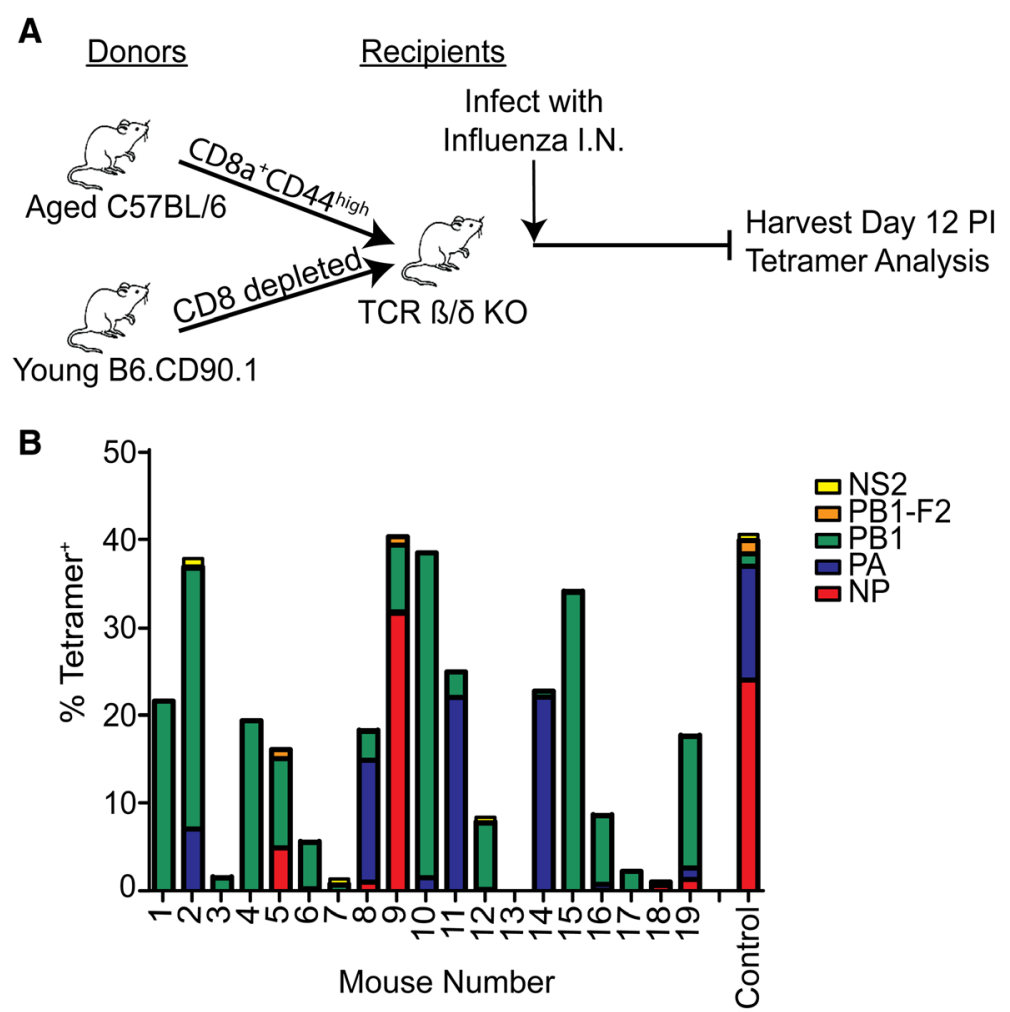

Fig. 1 Memory cells from naïve aged mice can respond to de novo infection with influenza. a Sorted CD44 ${ }^{\text {High }}$ memory CD8 T cells from naïve aged (18-22 months) mice were co-transferred with CD8 T cell-depleted splenocytes from young mice into T cell deficient TCR $\beta \delta-/-$ mice, infected with influenza virus, and the responding CD8 T cells analyzed at 12 days post infection. $\mathbf{b}$ The epitope-specific CD8 T cell response of 19 individual aged mice is indicated by colors and a young WT control mouse is shown

aged mice [7]. Consistent with this, analysis of adoptive transfers from 19 individual aged mice showed that the pattern of response to the two epitopes was heterogeneous in individual mice and was not consistent with what was typically seen in either primary or recall responses in young mice (Fig. 1b). In only one of the 19 adoptive transfers of aged mouse cells did we observe a dominant $\mathrm{NP}_{366} / \mathrm{D}^{\mathrm{b}}$ response after influenza infection. In three additional mice we observed a $\mathrm{PA}_{224} / \mathrm{D}^{\mathrm{b}}$ dominant response, and in nine mice we observed a $\mathrm{PB}_{703} / \mathrm{K}^{\mathrm{b}}$-dominant response (which in a young intact SPF mouse represents a sub-dominant epitope). These adoptive transfer data are consistent with our previous data showing a selective reduction in the ability of aged mice to mediate a response to the immunodominant $\mathrm{NP}_{366} / \mathrm{D}^{\mathrm{b}}$ epitope after influenza infection, which is highly variable in individual mice [7]. In order to ensure that the development of the immunodominant $\mathrm{NP}_{366} / \mathrm{D}^{\mathrm{b}}$ response in the aged mice was not impaired due to lack of some deficiency in the TCR $\beta \delta-/-$ mice, such as CD4 T cell help, we co-transferred CD8-depleted splenocytes from young, congenically disparate mice along with the aged memory CD8 $\mathrm{T}$ cells. The number of sorted CD44 ${ }^{\text {High }}$ memory cells transferred from individual mice was variable, depending upon the yield of cells from the sort, but this did not correlate with the reduction of the $\mathrm{NP}_{366} / \mathrm{D}^{\mathrm{b}}$ response (Additional file 1).

While these findings demonstrate skewing of the epitope diversity within the aged memory populations of cells, it is important to also take into consideration that $\mathrm{T}$ cell clonal expansions increase with aging and can be a contributing factor to the declining ratio of naïve:memory CD8 $\mathrm{T}$ cells. These clonal expansions could be a significant component of the transferred CD $44^{\text {High }}$ cells $[20,21,46,47]$. Therefore, to eliminate this complication in the current experiments, we routinely pre-screened aged mice and eliminated those mice with TCE, determined as described in the Materials and Methods.

\section{Competition between memory and naïve CD8 T cells from aged mice responding to de novo influenza virus infection}

The previous data show that memory CD8 T cells from influenza-naïve, aged mice could respond to influenza virus infection when they were transferred in isolation and were the only source of CD8 T cells. However, in order to understand whether these cells could dominate the response in the context of the total population of 
peripheral CD8 $\mathrm{T}$ cells from aged mice, it was important to determine the ability of these cells to compete with naïve $\mathrm{CD} 8 \mathrm{~T}$ cells. Therefore, we co-transferred naïve $\left(\mathrm{CD} 44^{\mathrm{Low}}\right)$ and memory $\left(\mathrm{CD} 44^{\text {High }}\right)$ cells from aged mice into TCR $\beta \delta-/-$ mice (as previously) in a 1:1 ratio (Fig. 2a). Cells were isolated from congenically distinct mice (Fig. 2b), to allow for the identification of naive and memory donor cells during the response. In an additional set of experiments, we co-transferred naïve and memory CD8 $\mathrm{T}$ cells in a 1:9 ratio, more typical of the ratio in aged mice. In both cases, as previously, we co-transferred CD8-depleted spleen cells from young mice, distinguished by a third congenic marker (see Figure legend for details).
The data (Fig. 2c) show that memory CD8 T cells made a minor contribution to de novo influenza infection in the bronchoalveolar lavage (BAL), lung tissue and spleen when the naive and memory cells were transferred in a 1:1 ratio, and a greater contribution to the response when the cells were transferred in a 1:9 ratio, a ratio more reflective of their natural distribution in aged mice. These data show that cross-reactive memory cells in aged, influenza-naive mice can make a major contribution to the response to a de novo influenza virus infection.

We also analyzed the epitope specificity of the response within these competitive transfer experiments (Fig. 2d). The repertoire of naïve CD8 T cells in the 1:1 transfer was

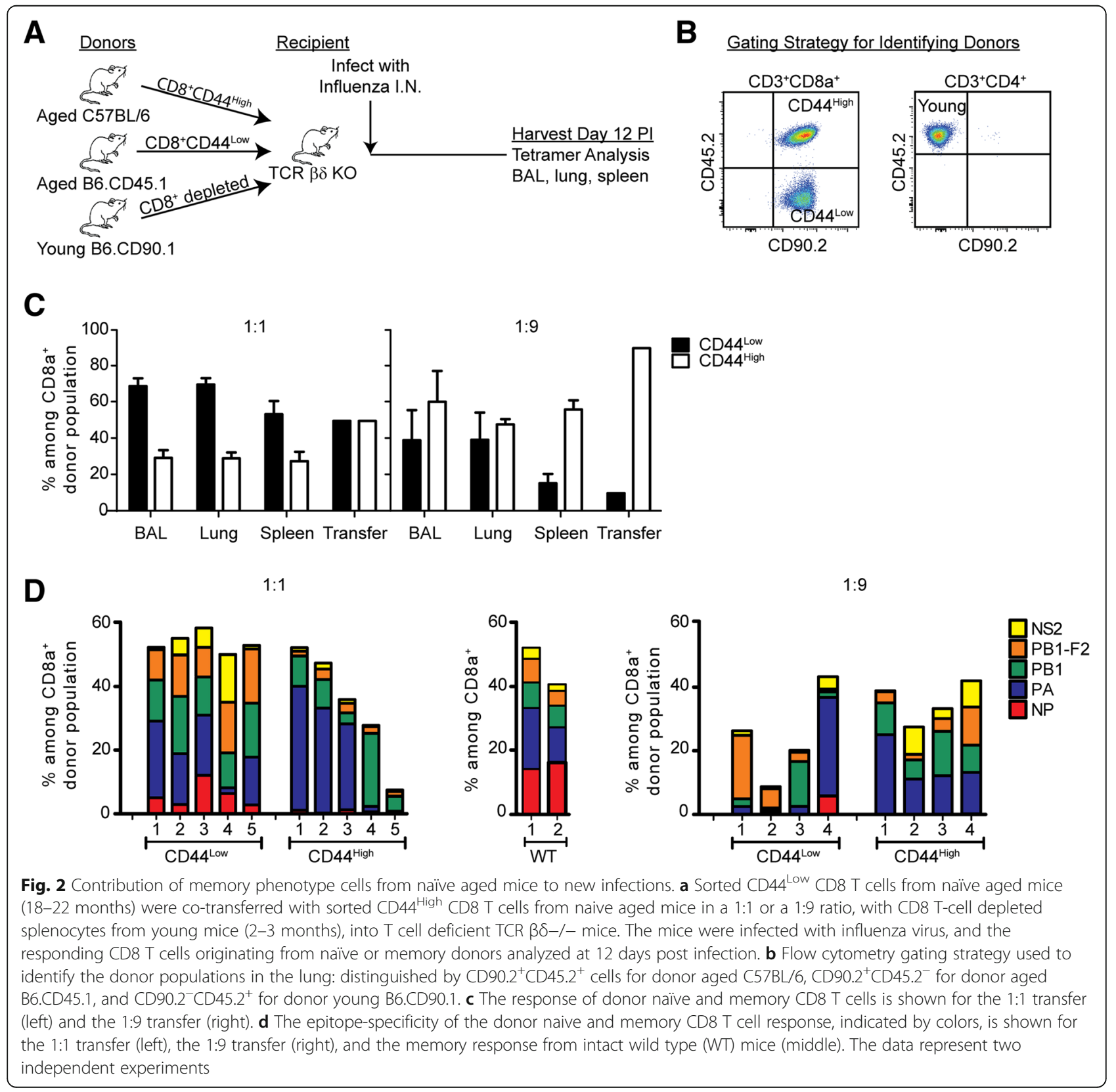


diverse, and consisted of responses to all 5 epitopes tested, reflective of the repertoire of wild type mice. In contrast, the repertoire of the responding memory cells in both the 1:1 and the 1:9 transfer was skewed from the normal response of naïve CD8 T cells, and varied greatly in individual mice. Together, these data support the hypothesis that cross-reactive memory CD8 T cells, not generated in response to influenza virus infection, make a major contribution to the response to a newly-encountered antigen in aged mice, with skewed repertoire diversity.

\section{Distribution of peripheral memory CD8 T cells in influenza memory mice infected when young or aged}

The previous data supported our hypothesis that in aged mice the naive CD8 $\mathrm{T}$ cell repertoire may become so constrained that responses to newly-encountered pathogens are mediated primarily by fortuitously cross reactive memory CD8 T cells, previously generated in response to unrelated antigens. The composition of the peripheral CD8 $\mathrm{T}$ cells in the spleen and lung of young mice is predominately of a naïve phenotype (CD44 ${ }^{\text {Low }}$ ), whereas the composition in aged mice is predominantly a memory phenotype $\left(\mathrm{CD} 44^{\mathrm{High}}\right)$, consistent with published data [42] (Fig. 3). Furthermore, memory phenotype cells in young mice were predominantly CM whereas aged mice had a large percentage of EM in addition to CM. Further analysis of the phenotype of the CM using the phenotypic markers CD62L and CD49d showed that cells with a virtual memory (VM) phenotype dominated the CM population in both young and aged mice. We termed the memory cells without a VM phenotype (CD49d $\left.\mathrm{d}^{\text {High }}\right)$, true memory (TM) cells. The low number of TM in aged mice raised the possibility that memory $\mathrm{T}$ cells of a VM rather than a TM phenotype responded to de novo influenza infection. Thus we next investigated whether the adoptively-transferred CD8 memory $\mathrm{T}$ cells responding to a primary influenza infection in aged mice originated from VM or TM cells.

\section{VM dominate the response of memory CD8 T cells from aged naïve mice to primary influenza virus infection}

To determine if the memory CD8 $\mathrm{T}$ cells that were responding during influenza infection of aged mice were of the TM or VM phenotype, the two populations were sorted from aged naïve B6 and congenic (B6.CD45.1) mice based on CD49d expression. Cells were then adoptively transferred into T cell-deficient (TCR $\beta \delta^{-/-}$) mice, along with CD8-depleted $\mathrm{T}$ cells from young congenic mice (B6.CD90.1), and infected with influenza virus, as shown (Fig. 4a). We then followed the response to $\mathrm{PA}_{224} / \mathrm{D}^{\mathrm{b}}$ since our previous findings demonstrated the low and variable nature of the $\mathrm{NP}_{366} / \mathrm{D}^{\mathrm{b}}$ response in aged mice (Figs. 1b and 2d). As shown in Fig. 4c, the influenza antigen-specific $\mathrm{T}$ cell response to the $\mathrm{PA}_{224} / \mathrm{D}^{\mathrm{b}}$ epitope was dominated by VM cells, with only a very small component arising from the adoptively transferred TM cells. Further examination of the antigen-specific $\mathrm{T}$ cell repertoire to the five major influenza epitopes in C57BL/6 mice reinforced the conclusion that the influenza-specific response of aged mice predominantly derives from VM cells (Fig. 4e). We also examined the phenotype of the antigen-specific $\mathrm{T}$ cells that developed in response to the influenza infection and found that all of the cells had upregulated CD49d, switching to a TM phenotype (Fig. 4d). Taken together, the data show that the response of memory CD8 T cells from influenza-naïve aged mice to a new influenza infection is predominantly mediated by VM cells and these VM cells then convert to a TM phenotype, consistent with previous observations [48].

\section{VM cells from aged mice generate functional effector cells}

In order to determine whether influenza virus reactive VM CD8 T cells were functional, we analyzed granzyme responses (Fig. 5a). Granzyme staining from representative individual mice is shown in Fig. 5b. The plotted data from two independent experiments (Fig. 5c) show the VM cells from aged, influenza-naïve mice developed a granzyme response at least as strong as that developed by the naïve $T$ cells from young mice at day 6 . By day 9 the response of both populations had waned.

The delay in viral clearance of influenza infection in aged mice has been well established [49]. However, our observations that naïve CD8 $\mathrm{T}$ cells from young mice and VM CD8 T cells from aged mice generate comparable granzyme responses prompted us to examine viral clearance (Fig. 6a). Therefore, we compared viral clearance mediated by young CD8 T cells (mostly naïve) and aged CD8 T cells (mostly VM). Unexpectedly, the kinetics of viral clearance in TCR $\beta \delta-/-$ mice into which young or aged CD8 $\mathrm{T}$ cells had been transferred was comparable. In order to rule out the possible participation of cytotoxic young CD4 T cells [50, 51], we eliminated young CD4 T cells from the co-transfer. The data (Fig. 6b) showed that the kinetics of viral clearance remained comparable between transferred CD8 T cells from young mice, which have mostly naive CD8 $\mathrm{T}$ cells and aged mice, which have mostly VM CD8 T cells. TCR $\beta \delta-/-$ mice that received no transferred $\mathrm{T}$ cells (Fig. 6c) failed to clear virus, indicating that the viral clearance we are detecting in panel $B$ is mediated by the transferred T cells.

Together, our data show that VM effectively produce granzyme and mediate viral clearance. These data are consistent with previous reports that VM protect against infectious challenge and mediate rapid effector function $[48,52,53]$, although it is possible that there are kinetic differences compared with TM, which have not been examined (in isolation) in this study. 


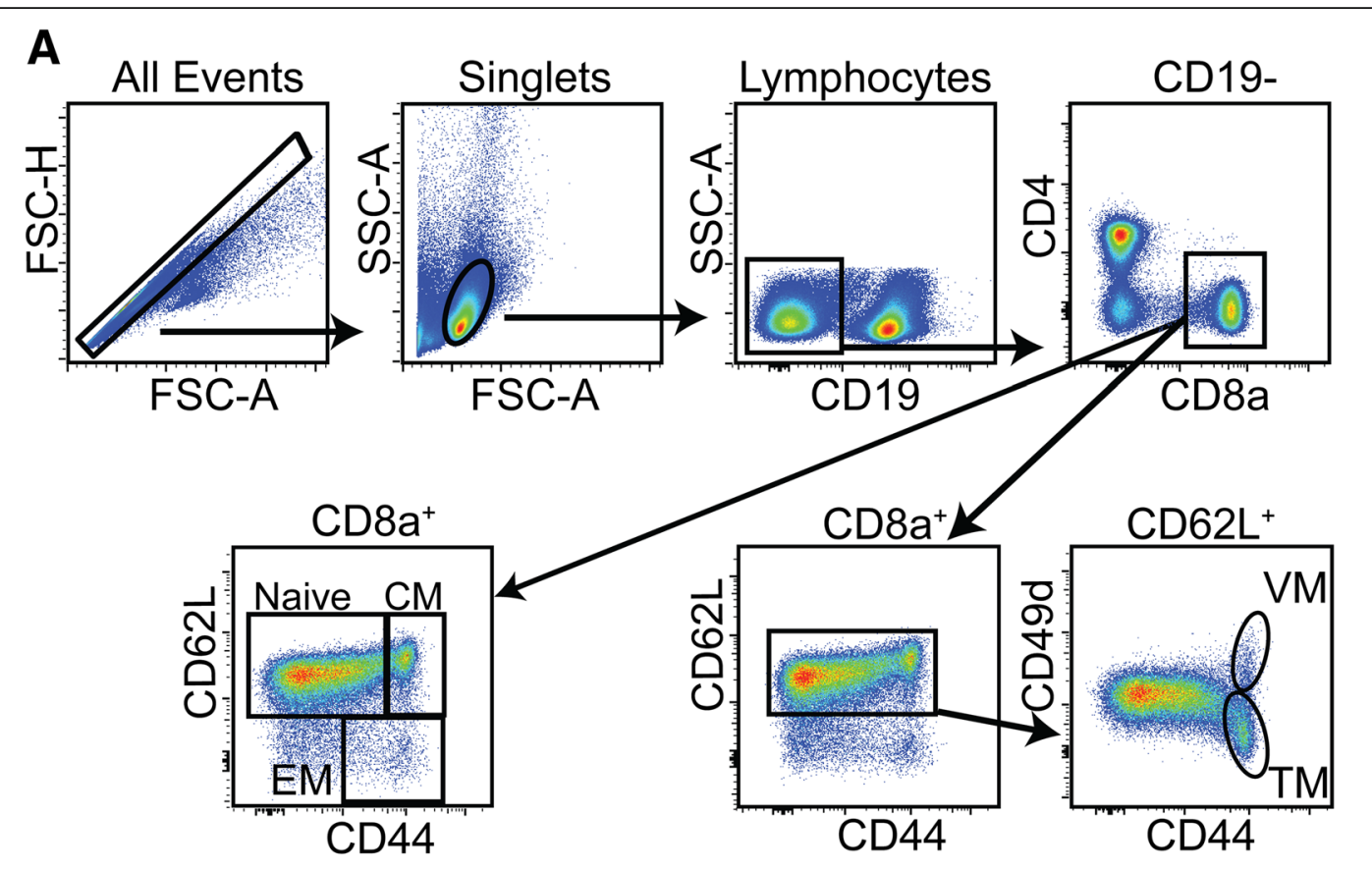

B

Spleen

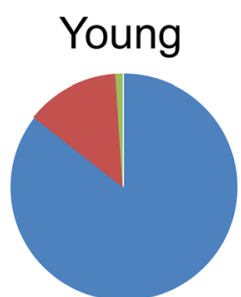

Naive $\square \mathrm{CM} \backsim \mathrm{EM}$

Lung
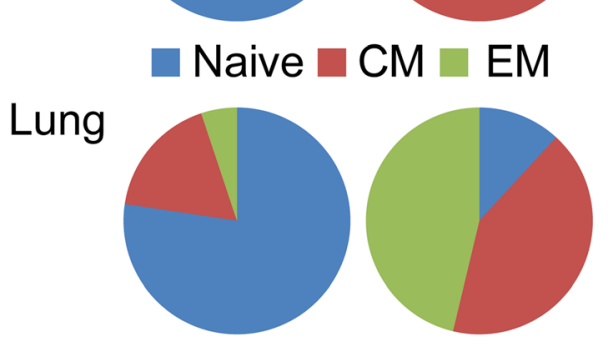

Aged

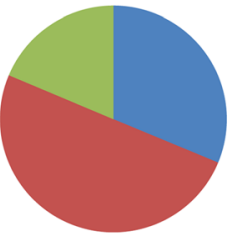

C

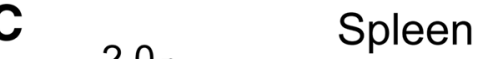

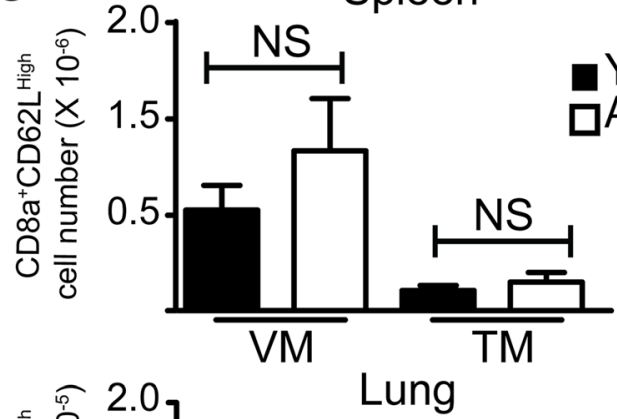

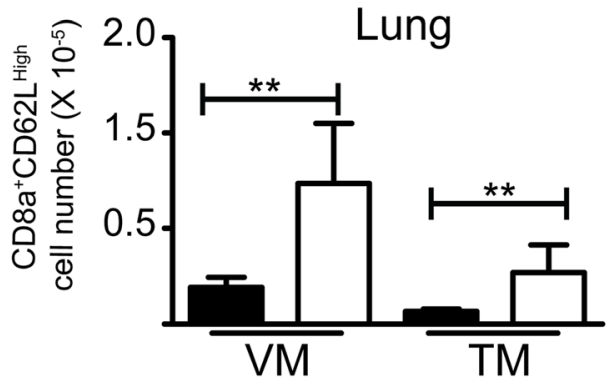

Fig. 3 Distribution of peripheral CD8 T cells in naive young and aged mice. a Representative flow cytometry staining from spleen illustrating the gating strategy for identifying CD8 subsets in B and C. $\mathbf{b}$ The distribution of naïve (CD62 $\left.\mathrm{L}^{\text {High }} / \mathrm{CD} 44 \mathrm{~L}^{\text {Low }}\right), \mathrm{CM}\left(\mathrm{CD} 62 \mathrm{~L}^{\text {High }} / \mathrm{CD} 44^{\text {High }}\right)$ and EM $\left(\mathrm{CD}_{2} \mathrm{~L}^{\mathrm{Low}} / \mathrm{CD} 44^{\mathrm{High}}\right)$ in the spleen and lung of young (2-3 months) and aged (18-22 months) SPF mice. $\mathbf{c}$ The number of VM (CD49d $\mathrm{d}^{\mathrm{Low}}$ ) and TM (CD49 $\left.\mathrm{d}^{\text {High }}\right)$ among the CM population in the spleen and lung of young and aged mice. Bars represent the mean \pm SD. The data are from a single experiment, $n=5$ mice/group, and are consistent with published data [42]. Data were analyzed by unpaired, two-tailed T test (** $p<0.01$ )

\section{Discussion}

It is well-established that there is a dramatic reduction in the number of naive CD8 $\mathrm{T}$ cells and a corresponding increase in the number of memory phenotype CD8 T cells in the periphery of aged mice. Because of the decline in numbers (and, consequently, repertoire diversity) of naïve cells, we hypothesized that the response of aged mice to new infections would be dominated by cross-reactive memory cells previously generated in response to other antigens during the lifespan, rather than from the pool of naive cells $[6,54]$. Using an adoptive transfer system, we have shown that, indeed, memory CD8 T cells from aged, influenza-naïve mice are capable of responding to influenza virus and developing into effector $\mathrm{T}$ cells that could 


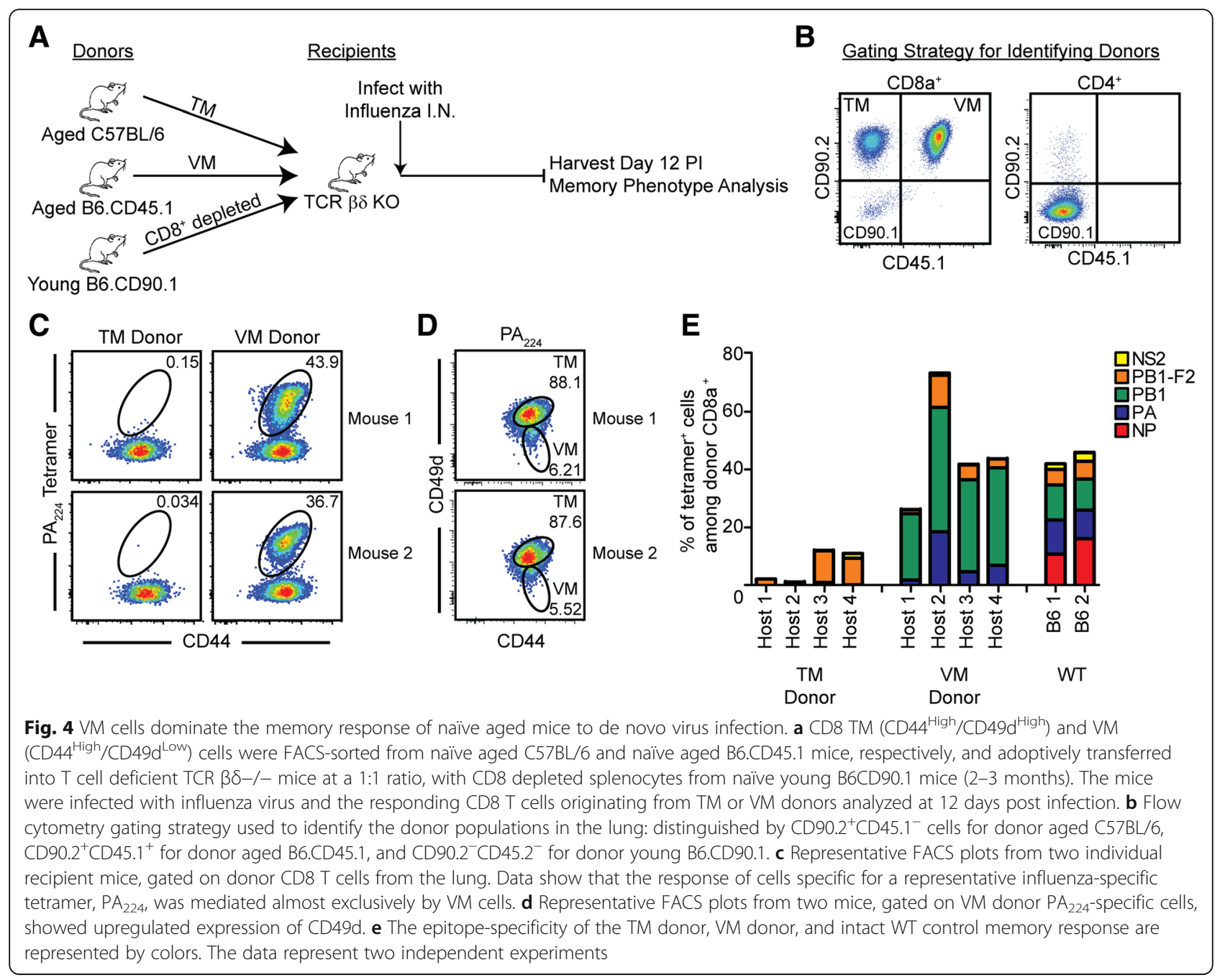

migrate to the sites of infection. Our dual adoptive transfer experiments showed that when naïve and memory CD8 $T$ cells were co-transferred at a ratio consistent with that found in aged mice (1:9), the memory $\mathrm{T}$ cells dominated the response. Yet the ability of adoptively transferred aged CD8 T cells to respond was outcompeted by the naive CD8 T cells when transferred at the 1:1 ratio. Furthermore, the epitope specificity of the memory $\mathrm{T}$ cell response was substantially constricted compared with naive $\mathrm{T}$ cells, and heterogeneous in individual mice, particularly with regard to the normally immunodominant epitope, NP (Fig. 1b). These data are consistent with previous studies by us [7] and others [9], showing reduced repertoire diversity following primary infection of intact aged mice.

Thus, our data support the hypothesis that the response to new antigens in aged mice is dominated by cross-reactive memory CD8 T cells. However, phenotypic analysis revealed that the memory cells were not "true" memory cells (TM), as would have been generated to previous infections. Instead, the memory cells had characteristics of VM, which are generated in the absence of antigen $[38,53,55,56]$. Importantly, the cells were found to be functional in terms of granzyme production and cleared virus upon influenza infection after adoptive transfer into young, T cell-deficient mice.

VM cells in mice appear in the periphery soon after birth in the absence of antigen [38, 48, 56-58], and accumulate with age in naïve specific pathogen free $(\mathrm{spf})$ mice [2, 41, 42, 59]. While the factors influencing the generation of VM are not completely understood, it has been hypothesized that these cells arise via different mechanisms in young and aged mice. For example, secondary TCR $\alpha$ rearrangements have been shown to be necessary for the age-related dominance of VM, indicating a requirement for TCR ligation in the generation of VM in aged mice, which was not a requirement in young mice [59]. Clearly, the mechanisms involved in VM cell generation, as well as the maintenance of these cells, need to be studied in both young and aged mice. 


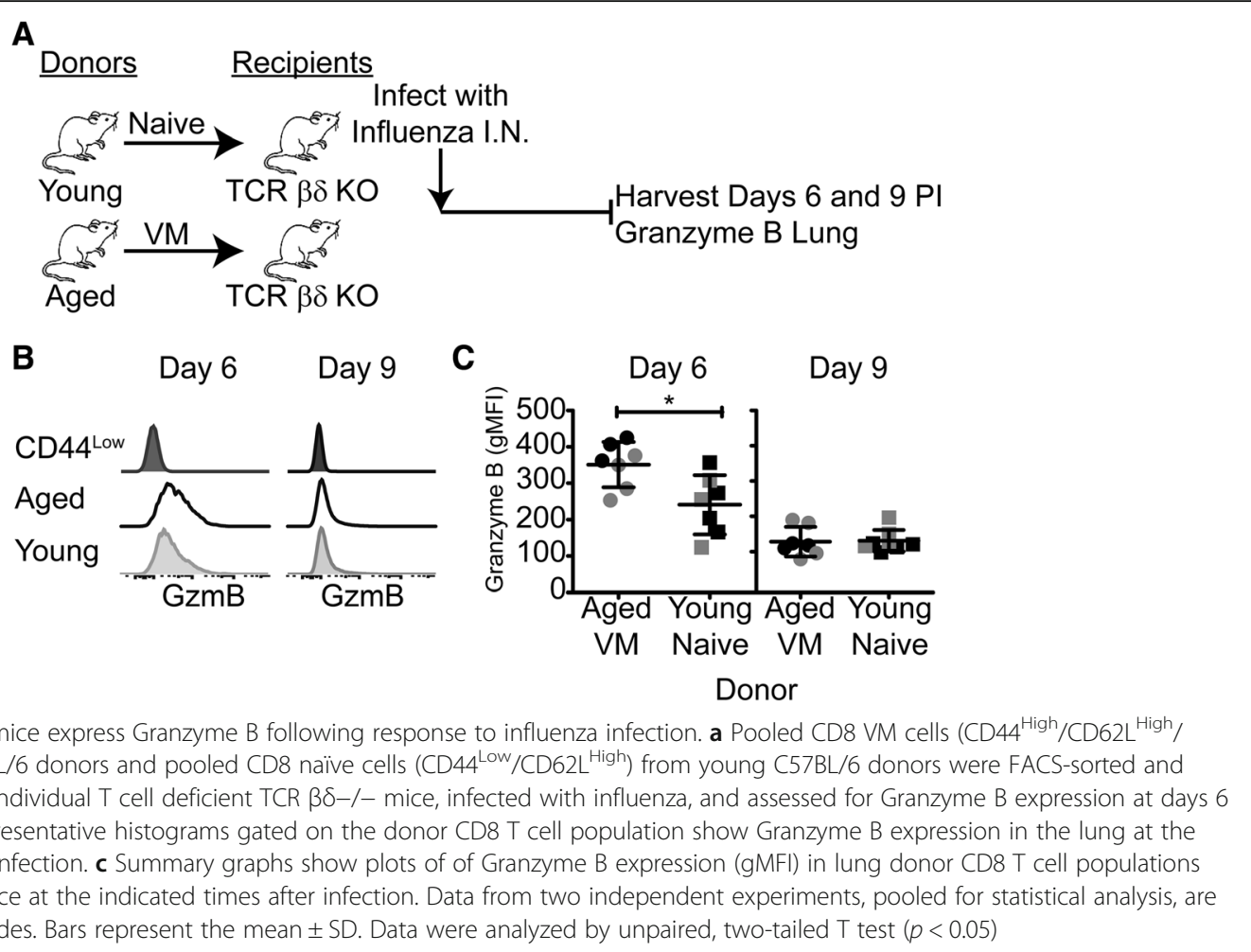

It has been shown that VM proliferate more robustly than naïve CD8 $\mathrm{T}$ cells after antigen stimulation of young mice $[38,48]$. However, we observed that aged memory cells were outcompeted by aged naïve CD8 T cells after influenza infection when transferred 1:1. This is consistent with the observation that VM in aged mice exhibit impaired TCR-mediated proliferation [59]. It has also been suggested that the antigen diversity of $\mathrm{VM}$ and naïve $\mathrm{T}$ cells is similar, because tetramer positive cells were identified in unprimed (young) animals to all epitopes tested [38]. However, this was not observed in our studies, as we saw a greater degree of epitope diversity in the response of naïve compared to VM CD8 T cells following influenza infection of aged mice (Fig. 2d).

Since our results demonstrated that the vast majority of the responding CD8 $\mathrm{T}$ cells that develop in the aged mice in response to influenza infection were from the population of VM cells, it was important to determine if these cells were capable of effector function. It has been shown that $\mathrm{VM}$ produce IFN $\gamma$, both in response to cognate antigen as well as cytokine-mediated, antigen independent stimulation $[38,39,48]$. In addition, VM have been shown to express granzyme, and can mediate antigen-independent bystander killing $[39,53]$. Consistent with these published data, our results show that VM cells from aged mice have the capacity to become granzyme-secreting effectors and clear virus with kinetics comparable to CD8 T cells from young, influenza-naïve mice. Interestingly, it has been shown that VM preferentially differentiate into CM after stimulation, whereas TM cells tend to become EM upon secondary challenge [48], suggesting that the response of VM to influenza infection may actually contribute to strong maintenance of memory. This intriguing idea was not directly examined in the current study.

A key question in the field of aging immunity is the relevance of the aged mouse model to elderly humans. Whereas naïve CD8 $\mathrm{T}$ cell repertoire diversity in the mouse declines to the extent that the ability to respond to new infections is impaired [3-6, 13, 22, 23] and "holes" in the repertoire can develop [7], it has been shown that there is only a modest (3-5-fold) reduction in CD8 T cell repertoire diversity with age in humans $[60,61]$. Thus, partly because of the increased total number of $\mathrm{T}$ cells in the human compared to mouse $\left(3 \times 10^{11}\right.$ compared to $1-$ $2 \times 10^{8}$ ) [62-64], the CD8 $\mathrm{T}$ cell repertoire in human remains reasonably diverse and unlikely to develop holes [65], as we have shown in the mouse [7]. However, in very old individuals, clonal expansions and loss of the proliferative capacity of $\mathrm{T}$ cells result in more dramatic reduction of the human $\mathrm{T}$ cell repertoire $[18,63,66,67]$, making the results in aged mice relevant.

Another important question is whether VM are found in humans and whether they increase with age, as has been shown for the mouse. Importantly, although the phenotypic markers differ from VM in mouse, a 
A
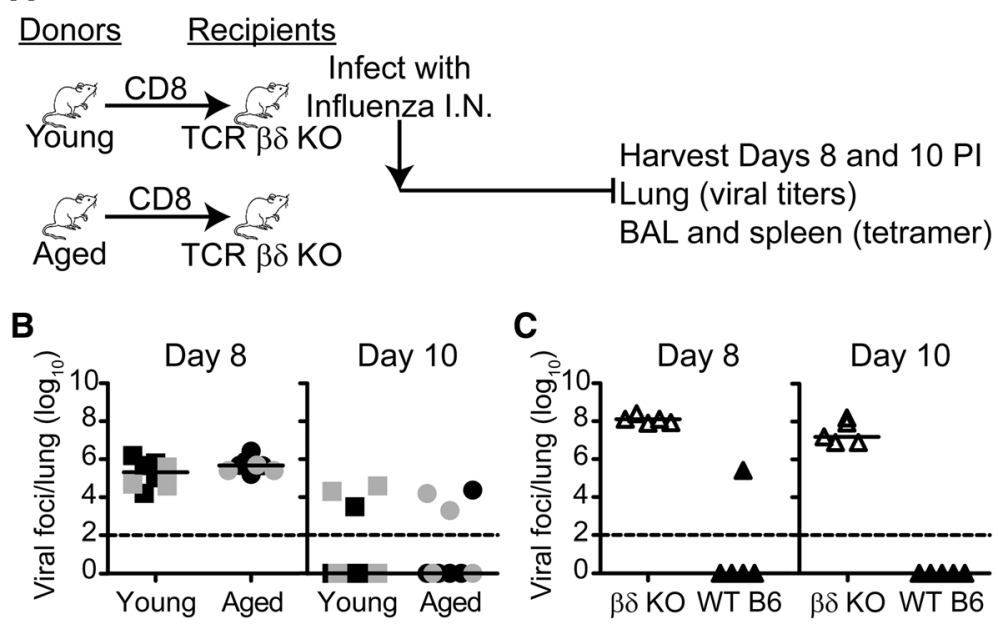

Fig. 6 Transferred CD8 cells from naïve aged and young mice clear virus with similar kinetics. a CD8 T cells from naive aged or young mice were enriched from splenocytes using negative selection, adoptively transferred into individual T cell deficient $\beta \delta-/-$ mice, infected with influenza virus, and the lungs were harvested at days 8 and 10 post-infection to determine viral titers. $\mathbf{b}$ Summary graphs of the viral foci/lung on days 8 and 10 post infection. Data from two independent experiments, pooled for statistical analysis, are represented in separate shades. Bars represent the median. Viral titers on day 8 or on day 10 in the two groups did not differ significantly $(p>0.05)$. Data were analyzed by Mann-Whitney Test. c Graph of the viral foci/lung on days 8 and 10 post infection for control individual WT C57BL/6 mice and individual T cell deficient $\beta \delta-/-$ mice that did not receive adoptively transferred CD8 T cells

population of CD8 $\mathrm{T}$ cells that functionally resembles VM has been identified in human, and these cells have been shown to increase with age in splenocytes and liver in human $[39,53]$. For example, the data showed an increase in human VM cells in the spleen from $\sim 5 \%$ at age 30 to $\sim 20 \%$ at age 65 [53]. The studies reported here show VM cells play a major role in the response of aged mice to new infections, whereas the impact of human VM cells on responsiveness of the elderly to new infections is unknown. To add to the complexity of peripheral memory CD8 $\mathrm{T}$ cells in aging, a novel population of memory cells with a naïve phenotype has recently been shown to accumulate with age in humans [68]. It remains to be determined if a similar population is found in aged mice.

In our studies, the CD8 memory $\mathrm{T}$ cell population in aged SPF mice was dominated by VM cells. We hypothesized that aged mice that have experienced infections during their lifespan comparable to humans would have a higher ratio of TM to VM. It has been argued that VM are not an artifact of spf housing of mice because VM are generated and persist after bystander activation during deliberate, unrelated infections [56] However, a single infection in the mouse is not comparable to a lifetime of infections, including persistent infections, in human. Newly-developed "dirty" mouse models will allow testing the possibility that spf housing explains the large population of VM cells [69-72]. It has not yet been determined whether VM dominate the peripheral repertoire of CD8 T cells in antigen-experienced (dirty), aged mice.

The knowledge that $\mathrm{T}$ cell immunity is long-lived has raised the suggestion that aggressive immunization in youth and middle age would prevent the decline in repertoire and function of CD8 T cells associated with aging, and provide an approach to enhancing vaccination efficacy for the elderly. In support of this, it has been shown that priming of mice at an early age to influenza virus results in preservation of numbers, repertoire and function of virus-specific memory CD8 $\mathrm{T}$ cells $[9,73]$. This is in stark contrast to the reduced repertoire diversity and impaired response of CD8 T cells that are observed following primary infection of aged mice [7, 9, 41]. Despite the apparent ability of VM cells to clear virus in the absence of specific immunization, it should be remembered that the response of TM out-competes the response of VM when directly compared [52, 55]. Thus, specifically increasing the population of TM by vaccination will likely reduce the impact of VM in aged, specific pathogen free mice to influenza virus infection, supporting the concept of vaccinations early in life. In light of the observation that VM differentiate into long-lived CM phenotype cells after priming [48], whereas TM develop preferentially into short-lived EM, it will be important in future studies to determine the contribution of VM and TM in response to infection in young mice and the contribution of each cell type to long-term maintenance of memory. 


\section{Conclusions}

In conclusion, the declining response of the elderly to new infections and vaccines is well-established and provides a compelling rationale for dissecting the impact of age-associated changes in the CD8 T cell repertoire and functional immune response to new infections, using the mouse model. Although the mouse model is robust, it is important to keep in mind differences between humans and mice and, where possible, validate findings in the mice with experiments in humans.

In the current studies, we have tested the hypothesis that in the face of declining numbers and repertoire diversity of naïve CD8 T cells in aged mice, responses are dominated by fortuitously cross-reactive memory cells. Adoptive transfer studies confirmed that memory CD8 T cells from influenza-naïve aged mice can respond to de novo infection with influenza virus in influenza-naïve aged mice with a highly constricted $\mathrm{T}$ cell receptor repertoire for the well characterized epitopes in C57BL/6 mice. Unexpectedly, the response was mediated by CD8 T cells with a virtual memory phenotype, rather than by true memory CD8 $\mathrm{T}$ cells previously generated in response to unrelated antigens. The VM CD8 T cells that dominated the repertoire in aged mice became functional granzyme B-producing effector cells and were able to clear influenza virus with a comparable kinetics to cells from young naïve mice. These data confirm the complexity of aging effects on the peripheral CD8 T cell repertoire.

\section{Methods}

\section{Mice and viral infections}

Female C57BL/6, B6.SJL-Ptprca Pepcb/BoyJ (B6.CD45.1), B6.PL-Thy1a/Cy (B6.CD90.1) and B6.129P2-Tcrb ${ }^{\text {tm1Mom }}$ Tcrd $^{\text {tm1Mom } / J}\left(\mathrm{TCR} \beta \delta^{-/-}\right)$were obtained from the Trudeau Institute animal facility or purchased from Jackson Laboratory and maintained under specific pathogen-free conditions. Often, but not always, impaired immune function has been attributed to the presence of large TCEs in the CD8 population [4, 7]. To avoid this complicating factor, peripheral blood lymphocytes of all aged mice were prescreened for major CD8 $\mathrm{T}$ cell $\mathrm{V} \beta$ expansions, and those that exhibited TCR V $\beta 8, \mathrm{~V} \beta 7$ or $\mathrm{V} \beta 8.3$ staining \pm 4 SD over that observed with young C57BL/6 mice were omitted from the study. Mice were anesthetized with 2,2,2,-tribromoethanol and infected intranasally (i.n.) with $3000 \mathrm{EID}_{50} \mathrm{~A} /$ HK- $\times 31(\times 31, H 3 N 2)$. All experiments were approved by the Institutional Animal Care and Use Committee of the Trudeau Insitute.

\section{Lymphocyte isolation and flow cytometry}

Lung tissue was prepared by coarsely chopping the tissue followed by incubation in a $0.5 \mathrm{mg} / \mathrm{mL}$ solution of collagenase D (Roche) and DNase (Sigma Aldrich) for 30-45 min at $37{ }^{\circ} \mathrm{C}$. Lymphocytes were enriched from digested lung tissue by differential centrifugation, using a gradient of $40 / 80 \%$ Percoll (GE Healthcare). Single-cell suspensions were prepared from lymph nodes and spleens by dispersing the tissues through a $70 \mu \mathrm{m}$ cell mesh. Single-cell suspensions were incubated with Fc-block (anti-CD16/32) for $15 \mathrm{~min}$ on ice followed by staining with MHC class I tetramer reagents for one hour at room temperature. Tetramer-labeled cells were then washed and stained with fluorochrome-conjugated antibodies against CD4, CD8 $\alpha$, CD19, CD90.2 (BD); CD44, CD45.1, CD45.2, CD62L (BioLegend); CD44 and CD49d (eBioscience) for $30 \mathrm{~min}$ on ice. MHC class I peptide tetramers specific for influenza virus $\mathrm{NP}_{366} / \mathrm{D}^{\mathrm{b}}$, $\mathrm{PA}_{224} /{ }^{\mathrm{Db}}, \mathrm{PB}_{703} / \mathrm{K}^{\mathrm{b}}, \mathrm{PB} 1-\mathrm{F} 2_{62} / \mathrm{D}^{\mathrm{b}}$, and $\mathrm{NS} 2_{114} / \mathrm{K}^{\mathrm{b}}$ were generated by the Trudeau Institute Molecular Biology Core Facility. For granzyme B staining, cells were fixed and permeabilized using the Cytofix/Cytoperm kit (BD) after tetramer and surface marker staining. Cells were stained with anti-granzyme B (or isotype control) antibody conjugated to PE (Invitrogen). Stained samples were run on a FACS Canto II or LSRII flow cytometer (BD Biosciences) and data were analyzed with FloJo software (TreeStar).

\section{Isolation of CD8 $\mathrm{T}$ cell subpopulations}

Spleen and superficial lymph nodes were harvested from young (2-3 months) or aged (18-22 months) mice, processed into single-cell suspensions as described above, and further enriched by negative selection for CD8 cells using the BD Mouse CD8 T Lymphocyte Enrichment Kit. Sorting was performed on a BD Influx cell sorter with BD FACS Sortware software. Combinations of CD45 and CD90 alleles were chosen to allow discrimination of co-transferred populations, as shown in figures, where applicable.

In studies described in Figs. 1, 2 and 4, sorted cell populations were transferred, along with CD8-depleted splenocytes from young (2-3 month) B6.CD90.1 donors, into young TCR-deficient hosts $\left(\mathrm{TCR} \beta \delta^{-/-}\right)$via intravenous injection. For the studies described in Fig. 1, CD8 T cells were enriched from pooled spleen and lymph nodes from individual naive aged (18-22 months) mice and sorted to isolate the CD $44^{\text {High }}$ CD8 T cells. Total sorted cells, along with CD8 depleted splenocytes from young (2-3 month) B6.CD90.1 donors, were transferred into individual young $\mathrm{TCR} \beta \delta^{-/-}$hosts via intravenous injection. Recipient mice were infected i.n. with X-31 influenza virus (H3N2, $3000 \mathrm{EID}_{50} /$ mouse) 1 day after transfer. BAL, lung and spleen were harvested for analyses at day 12 following infection. Responding donor CD8 T cells were identified and enumerated through the use of antibody staining and MHC class I tetramers.

For studies described in Fig. 2, CD8 T cells were enriched from pooled spleen and lymph nodes from naïve aged (1822 months) B6.CD45.1 or C57BL/6 mice and sorted to 
isolate the CD44 ${ }^{\text {High }}$ and CD44 ${ }^{\text {Low }} \mathrm{CD} 8 \mathrm{~T}$ cells. After sorting, the cells were transferred at either a 1:1 or 1:9 ratio of $\mathrm{CD} 44^{\text {Low }}: \mathrm{CD} 44^{\text {High }}$, along with CD8-depleted splenoctyes from young (2-3 month) B6.CD90.1 donors, into young $\mathrm{TCR} \beta \delta^{-/-}$hosts. Recipient mice were infected i.n. with $\mathrm{X}$-31 influenza virus (H3N2, $3000 \mathrm{EID}_{50} /$ mouse) 1 day after transfer. BAL, lung and spleen were harvested for analyses at day 12 following infection. Responding donor CD8 T cells were identified and enumerated through the use of antibody staining and MHC class I tetramers.

For studies described in Fig. 4, CD8 T cells were enriched from pooled spleen and lymph nodes from naïve aged (18-22 months) B6.CD45.1 or B6.CD45.2 mice and sorted to isolate the TM $\left(\mathrm{CD} 62 \mathrm{~L}^{\mathrm{High}} \mathrm{CD} 44^{\mathrm{High}} \mathrm{CD} 49 \mathrm{~d}^{\mathrm{High}}\right)$ and the VM (CD62 $\left.\mathrm{L}^{\text {High }} \mathrm{CD} 44^{\text {High }} \mathrm{CD} 49 \mathrm{~d}^{\text {Low }}\right) \mathrm{CD} 8 \mathrm{~T}$ cells. The sorted cells were adoptively transferred into young $\mathrm{TCR} \beta \delta^{-/}$hosts at a 1:1 ratio. Recipient mice were infected i.n. with X-31 influenza virus (H3N2, 3000 EID $_{50} /$ mouse) 1 day after transfer. BAL, lung and spleen were harvested for analyses at day 12 following infection. Responding donor CD8 $\mathrm{T}$ cells were identified and enumerated through the use of antibody staining and MHC class I tetramers.

For studies described in Fig. 5, CD8 T cells were enriched from pooled spleen and lymph nodes from naïve young (2-3 months) or naïve aged (18-22 months) mice and sorted to isolate the CD44 $4^{\mathrm{Low}} \mathrm{CD} 8 \mathrm{~T}$ cells or the $\mathrm{CD}_{62} \mathrm{~L}^{\text {High }} \mathrm{CD} 44^{\mathrm{High}} \mathrm{CD} 49 \mathrm{~d}^{\text {Low }} \mathrm{CD} 8 \mathrm{~T}$ cells, respectively. Sorted cells from young or aged mice were transferred into young TCR $\beta \delta^{-1-}$ hosts. Recipient mice were infected i.n. with X-31 influenza virus (H3N2, 3000 EID $_{50} /$ mouse) 1 day after transfer. BAL, lung and spleen were harvested for analyses at days 6 and 9 following infection. Responding donor CD8 T cells were identified and enumerated through the use of antibody staining and MHC class I tetramers, and evaluated for Granzyme B expression.

For studies described in Fig. 6, spleen and superficial lymph nodes were harvested from naive young (2-3 months) or aged (18-22 months) mice, pooled, and enriched by negative selection for $\mathrm{CD}^{+}$cells using the $\mathrm{BD}$ Mouse $\mathrm{CD} 8$ T Lymphocyte Enrichment Kit. $2.5 \times 10^{6}$ enriched CD8 T cells from either young or aged mice were transferred into young TCR $\beta \delta^{-/-}$hosts. Recipient mice were infected i.n. with X-31 influenza virus (H3N2, $3000 \mathrm{EID}_{50} /$ mouse) 1 day after transfer. Lungs were harvested from recipient mice at days 8 and 10 and processed for viral titers. In a separate control experiment, young TCR $\beta \delta^{-/-}$with no T cell transfer and young C57BL/6 mice were infected i.n. with X-31 influenza virus (H3N2, $3000 \mathrm{EID}_{50} /$ mouse). Lungs were harvested at days 8 and 10 and processed for viral titers.

\section{Measurement of viral load}

Whole lung tissue was harvested in PBS at the indicated times, homogenized, and stored at $-70{ }^{\circ} \mathrm{C}$. Virus titers were measured with a standard plaque assay by infecting MDCK cell monolayers with serial 5-fold dilutions of lung suspension in duplicate. Eighteen to twenty-four hours after infection, monolayers were washed and fixed with $80 \%$ acetone in water. Infected cell clusters were detected with a biotin-labeled mouse anti-influenza A monoclonal antibody (Chemicon), followed by staining with streptavidin-AP, and visualized with Sigma Fast BCIP/NBT substrate (Sigma). The number of viral-foci units (VFUs) was counted, and the data were shown as the VFU/lung.

\section{Statistical analysis}

Statistical analysis was performed with GraphPad Prism 5 software (GraphPad, San Diego, CA). Differences were considered significant at $p$ value $<0.05$.

\section{Additional file}

Additional file 1: Table S1. Cell transfer number and tetramer frequency for individual aged mice transfer study. (DOCX $14 \mathrm{~kb}$ )

\section{Abbreviations}

BAL: Bronchoalveolar lavage; CM: Central memory; EM: Effector memory; NP: Nucleoprotein; TM: "True" memory; $T_{\text {RM: }}$ Resident memory; VM: Virtual memory

\section{Acknowledgements}

We thank Drs. David Woodland and Laura Haynes for helpful discussion and reviewing the manuscript, Dr. Larry Johnson for help with statistical analysis and Drs. Suzy Swain and Janet McElhaney for comments and discussion. We thank the Molecular Biology Core at Trudeau Institute for providing the MHC class I tetramers and the Animal Care facility at Trudeau Institute for breeding and maintaining the aged mice.

\section{Funding}

This work was supported by the National Institutes of Health grants P01 AG021600, project 4 (M.A.B), R01 AG039485 (M.A.B) and funds from the Trudeau Institute.

\section{Availability of data and materials}

The datasets used and analyzed during the current study are available from the corresponding author on reasonable request.

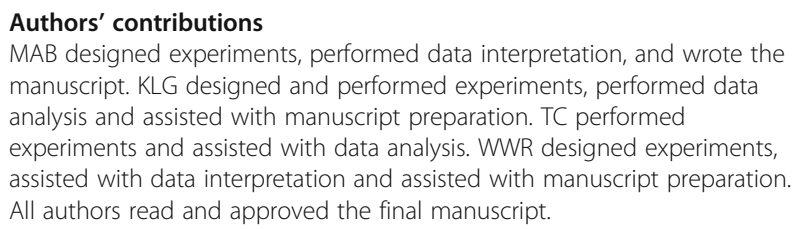

Ethics approval

Animal housing and procedures were approved by the Animal Care and Use Committee of Trudeau Institute.

Consent for publication

Not applicable.

Competing interests

The authors declare that they have no competing interests. 


\section{Publisher's Note}

Springer Nature remains neutral with regard to jurisdictional claims in published maps and institutional affiliations.

Received: 27 February 2018 Accepted: 18 July 2018

Published online: 08 August 2018

\section{References}

1. Yewdell JW, Haeryfar SM. Understanding presentation of viral antigens to CD8 (+) T cells in vivo: the key to rational vaccine design *. Annu Rev Immunol. 2005:23:651-82.

2. Rudd BD, Venturi V, Li G, Samadder P, Ertelt JM, Way SS, et al. Nonrandom attrition of the naive CD8+ T-cell pool with aging governed by T-cell receptor:pMHC interactions. Proc Natl Acad Sci U S A. 2011;108:13694-9.

3. Messaoudi I, Guevara Patino JA, Dyall R, LeMaoult J, Nikolich-Zugich J. Direct link between MHC polymorphism, T cell avidity, and diversity in immune defense. Science. 2002;298:1797-800.

4. Messaoudi I, Lemaoult J, Guevara-Patino JA, Metzner BMNikolich-Zugich J. Age-related CD8 T cell clonal expansions constrict CD8 T cell repertoire and have the potential to impair immune defense. J Exp Med. 2004; 200:1347-58.

5. Nikolich-Zugich J, Slifka MK, Messaoudi I. The many important facets of Tcell repertoire diversity. Nat Rev Immunol. 2004;4:123-32.

6. Woodland DL, Blackman MA. Immunity and age: living in the past? Trends Immunol. 2006;27:303-7.

7. Yager EJ, Ahmed M, Lanzer K, Randall TD, Woodland DL, Blackman MA. Ageassociated decline in $\mathrm{T}$ cell repertoire diversity leads to holes in the repertoire and impaired immunity to influenza virus. J Exp Med. 2008;205:711-23.

8. Ahmed M, Lanzer KG, Yager EJ, Adams PS, Johnson LL, Blackman MA. Clonal expansions and loss of receptor diversity in the naive CD8 T cell repertoire of aged mice. J Immunol. 2009;182:784-92.

9. Valkenburg SA, Venturi V, Dang TH, Bird NL, Doherty PC, Turner SJ, et al. Early priming minimizes the age-related immune compromise of CD8(+) $T$ cell diversity and function. PLoS Pathog. 2012;8:e1002544.

10. Johnson PL, Goronzy JJ, Antia R. A population biological approach to understanding the maintenance and loss of the T-cell repertoire during aging. Immunology. 2014:142:167-75.

11. Gil A, Yassai MB, Naumov YN, Selin LK. Narrowing of human influenza a virus-specific T cell receptor alpha and beta repertoires with increasing age. J Virol. 2015;89:4102-16.

12. Yoshida K, Cologne JB, Cordova K, Misumi M, Yamaoka M, Kyoizumi S, et al. Aging-related changes in human T-cell repertoire over 20 years delineated by deep sequencing of peripheral T-cell receptors. Exp Gerontol. 2017;96: 29-37.

13. Smithey MJ, Li G, Venturi V, Davenport MP, Nikolich-Zugich J. Lifelong persistent viral infection alters the naive T cell pool, impairing CD8 T cell immunity in late life. J Immunol. 2012;189:5356-66.

14. Britanova OV, Putintseva EV, Shugay M, Merzlyak EM, Turchaninova MA Staroverov DB, et al. Age-related decrease in TCR repertoire diversity measured with deep and normalized sequence profiling. J Immunol. 2014;192:2689-98.

15. Lee JB, Oelke M, Ramachandra L, Canaday DH, Schneck JP. Decline of influenza-specific CD8+ T cell repertoire in healthy geriatric donors. Immun Ageing. 2011;8:6

16. Sempowski GD, Gooding ME, Liao HX, Le PT, Haynes BF. T cell receptor excision circle assessment of thymopoiesis in aging mice. Mol Immunol. 2002;38:841-8

17. Effros RB, Cai Z, Linton PJ. CD8 T cells and aging. Crit Rev Immunol 2003;23:45-64

18. Naylor K, Li G, Vallejo AN, Lee WW, Koetz K, Bryl E, et al. The influence of age on T cell generation and TCR diversity. J Immunol. 2005;174:7446-52.

19. Lerner A, Yamada T, Miller RA. Pgp-1 hi T lymphocytes accumulate with age in mice and respond poorly to concanavalin a. Eur J Immunol. 1989;19:977-82.

20. Callahan JE, Kappler JW, Marrack P. Unexpected expansions of CD8-bearing cells in old mice. J Immunol. 1993;151:6657-69.

21. Posnett DN, Sinha R, Kabak S, Russo C. Clonal populations of T cells in normal elderly humans: the T cell equivalent to "benign monoclonal gammapathy". J Exp Med. 1994;179:609-18.

22. Brien JD, Uhrlaub JL, Hirsch A, Wiley CA, Nikolich-Zugich J. Key role of T cell defects in age-related vulnerability to West Nile virus. J Exp Med. 2009;206: 2735-45.
23. Cicin-Sain L, Smyk-Pearson S, Currier N, Byrd L, Koudelka C, Robinson T, et al. Loss of naive $T$ cells and repertoire constriction predict poor response to vaccination in old primates. J Immunol. 2010;184:6739-45.

24. Brehm MA, Pinto AK, Daniels KA, Schneck JP, Welsh RM, Selin LK. T cell immunodominance and maintenance of memory regulated by unexpectedly cross-reactive pathogens. Nat Immunol. 2002;3:627-34.

25. Shimojo N, Cowan EP, Engelhard VH, Maloy WL, Coligan JE, Biddison WE. A single amino acid substitution in HLA-A2 can alter the selection of the cytotoxic T lymphocyte repertoire that responds to influenza virus matrix peptide 55-73. J Immunol. 1989;143:558-64.

26. Selin LK, Cornberg M, Brehm MA, Kim SK, Calcagno C, Ghersi D, et al. CD8 memory T cells: cross-reactivity and heterologous immunity. Semin Immunol. 2004;16:335-47.

27. Selin LK, Welsh RM. Plasticity of T cell memory responses to viruses. Immunity. 2004:20:5-16.

28. Welsh RM, Selin LK, Szomolanyi-Tsuda E. Immunological memory to viral infections. Annu Rev Immunol. 2004;22:711-43.

29. Kim SK, Cornberg M, Wang XZ, Chen HD, Selin LK, Welsh RM. Private specificities of CD8 T cell responses control patterns of heterologous immunity. J Exp Med. 2005;201:523-33.

30. Welsh RM, Che JW, Brehm MA, Selin LK. Heterologous immunity between viruses. Immunol Rev. 2010;235:244-66.

31. Che JW, Selin LK, Welsh RM. Evaluation of non-reciprocal heterologous immunity between unrelated viruses. Virol. 2015;482:89-97.

32. Su LF, Kidd BA, Han A, Kotzin JJ, Davis MM. Virus-specific CD4 (+) memoryphenotype T cells are abundant in unexposed adults. Immunity. 2013;38:373-83.

33. Mason D. A very high level of crossreactivity is an essential feature of the Tcell receptor. Immunol Today. 1998;19:395-404.

34. Sallusto F, Lenig D, Forster R, Lipp M, Lanzavecchia A. Two subsets of memory $T$ lymphocytes with distinct homing potentials and effector functions. Nature. 1999;401:708-12.

35. Masopust D, Vezys $V$, Marzo AL, Lefrancois L. Preferential localization of effector memory cells in nonlymphoid tissue. Science. 2001;291:2413-7.

36. Sallusto F, Geginat J, Lanzavecchia A. Central memory and effector memory T cell subsets: function, generation, and maintenance. Annu Rev Immunol. 2004:22:745-63.

37. Gerlach C, Loughhead SM, von Andrian UH. Figuring fact from fiction: unbiased polling of memory T cells. Cell. 2015;161:702-4.

38. Haluszczak C, Akue AD, Hamilton SE, Johnson LD, Pujanauski L, Teodorovic $L$, et al. The antigen-specific CD8+ T cell repertoire in unimmunized mice includes memory phenotype cells bearing markers of homeostatic expansion. J Exp Med. 2009;206:435-48.

39. White JT, Cross EW, Kedl RM. Antigen-inexperienced memory CD8+ T cells: where they come from and why we need them. Nat Rev Immunol. 2017; 17(6):391.

40. Lee $Y$ J, Jameson SC, Hogquist KA. Alternative memory in the CD8 T cell lineage. Trends Immunol. 2011:32:50-6.

41. Decman V, Laidlaw BJ, Doering TA, Leng J, Ertl HC, Goldstein DR, et al. Defective CD8 $T$ cell responses in aged mice are due to quantitative and qualitative changes in virus-specific precursors. J Immunol. 2012; 188:1933-41.

42. Chiu BC, Martin BE, Stolberg VR, Chensue SW. Cutting edge: central memory CD8 T cells in aged mice are virtual memory cells. J Immunol. 2013;191:5793-6.

43. Belz GT, Xie W, Altman JD, Doherty PC. A previously unrecognized H-2D (b)-restricted peptide prominent in the primary influenza a virus-specific CD8 (+) T-cell response is much less apparent following secondary challenge. J Virol. 2000;74:3486-93.

44. Crowe SR, Turner SJ, Miller SC, Roberts AD, Rappolo RA, Doherty PC, et al. Differential antigen presentation regulates the changing patterns of CD8+ T cell immunodominance in primary and secondary influenza virus infections. J Exp Med. 2003;198:399-410.

45. Ballesteros-Tato A, Leon B, Lee BO, Lund FE, Randall TD. Epitope-specific regulation of memory programming by differential duration of antigen presentation to influenza-specific CD8 (+) T cells. Immunity. 2014:41:127-40.

46. LeMaoult J, Messaoudi I, Manavalan JS, Potvin H, Nikolich-Zugich D, Dyall R, et al. Age-related dysregulation in CD8 T cell homeostasis: kinetics of a diversity loss. J Immunol. 2000;165:2367-73.

47. Kohlmeier JE, Connor LM, Roberts AD, Cookenham T, Martin K, Woodland $\mathrm{DL}$. Nonmalignant clonal expansions of memory CD8+ T cells that arise with age vary in their capacity to mount recall responses to infection. J Immunol. 2010;185:3456-62. 
48. Lee JY, Hamilton SE, Akue AD, Hogquist KA, Jameson SC. Virtual memory CD8 T cells display unique functional properties. Proc Natl Acad Sci U S A. 2013;110:13498-503.

49. Toapanta FR, Ross TM. Impaired immune responses in the lungs of aged mice following influenza infection. Respir Res. 2009;10:112.

50. Brown DM, Roman E, Swain SL. CD4 T cell responses to influenza infection. Semin Immunol. 2004;16:171-7.

51. Brown DM, Dilzer AM, Meents DL, Swain SL. CD4 T cell-mediated protection from lethal influenza: perforin and antibody-mediated mechanisms give a one-two punch. J Immunol. 2006;177:2888-98.

52. Hamilton SE, Wolkers MC, Schoenberger SP, Jameson SC. The generation of protective memory-like CD8+ T cells during homeostatic proliferation requires CD4+ T cells. Nat Immunol. 2006;7:475-81.

53. White JT, Cross EW, Burchill MA, Danhorn T, McCarter MD, Rosen HR, et al. Virtual memory $T$ cells develop and mediate bystander protective immunity in an IL-15-dependent manner. Nat Commun. 2016;7:11291.

54. Blackman MA, Woodland DL. The narrowing of the CD8 T cell repertoire in old age. Curr Opin Immunol. 2011;23:537-42.

55. Cheung KP, Yang E, Goldrath AW. Memory-like CD8+ T cells generated during homeostatic proliferation defer to antigen-experienced memory cells. J Immunol. 2009;183:3364-72.

56. Akue AD, Lee JY, Jameson SC. Derivation and maintenance of virtual memory CD8 T cells. J Immunol. 2012;188:2516-23.

57. Goldrath AW. Maintaining the status quo: T-cell homeostasis. Microbes Infect. 2002:4:539-45.

58. Jameson SC, Lee YJ, Hogquist KA. Innate memory T cells. Adv Immunol. 2015;126:173-213.

59. Renkema KR, Li G, Wu A, Smithey MJ, Nikolich-Zugich J. Two separate defects affecting true naive or virtual memory $T$ cell precursors combine to reduce naive T cell responses with aging. J Immunol. 2014;192:151-9.

60. Kim C, Fang F, Weyand CM, Goronzy JJ. The life cycle of a T cell after vaccination - where does immune ageing strike? Clin Exp Immunol. 2017;187:71-81.

61. Qi Q, Liu Y, Cheng Y, Glanville J, Zhang D, Lee JY, et al. Diversity and clonal selection in the human T-cell repertoire. Proc Natl Acad Sci U S A. 2014;111: 13139-44.

62. Arstila TP, Casrouge A, Baron V, Even J, Kanellopoulos J, Kourilsky P. A direct estimate of the human alphabeta T cell receptor diversity. Science. 1999; 286:958-61.

63. Goronzy JJ, Weyand CM. T cell development and receptor diversity during aging. Curr Opin Immunol. 2005;17:468-75.

64. Casrouge A, Beaudoing E, Dalle S, Pannetier C, Kanellopoulos J, Kourilsky P. Size estimate of the alpha beta TCR repertoire of naive mouse splenocytes. J Immunol. 2000;164:5782-7.

65. Goronzy JJ, Qi Q, Olshen RA, Weyand CM. High-throughput sequencing insights into T-cell receptor repertoire diversity in aging. Genome Med. 2015;7:117.

66. Hadrup SR, Strindhall J, Kollgaard T, Seremet T, Johansson B, Pawelec G, et al. Longitudinal studies of clonally expanded CD8 T cells reveal a repertoire shrinkage predicting mortality and an increased number of dysfunctional cytomegalovirus-specific T cells in the very elderly. J Immunol. 2006;176:2645-53.

67. Schwanninger A, Weinberger B, Weiskopf D, Herndler-Brandstetter D, Reitinger S, Gassner C, et al. Age-related appearance of a CMV-specific highavidity CD8+ T cell clonotype which does not occur in young adults. Immun Ageing. 2008;5:14.

68. Pulko V, Davies JS, Martinez C, Lanteri MC, Busch MP, Diamond MS, et al Human memory $T$ cells with a naive phenotype accumulate with aging and respond to persistent viruses. Nat Immunol. 2016;17(8):966.

69. Reese TA, Bi K, Kambal A, Filali-Mouhim A, Beura LK, Burger MC, et al. Sequential infection with common pathogens promotes human-like immune gene expression and altered vaccine response. Cell Host Microbe. 2016;19:713-9.

70. Beura LK, Hamilton SE, Bi K, Schenkel JM, Odumade OA, Casey KA, et al. Normalizing the environment recapitulates adult human immune traits in laboratory mice. Nature. 2016;532:512-6.

71. Abolins S, King EC, Lazarou L, Weldon L, Hughes L, Drescher $P$, et al. The comparative immunology of wild and laboratory mice, Mus muscdomesticus. Nat Commun. 2017;8:14811.
72. Rosshart SP, Vassallo BG, Angeletti D, Hutchinson DS, Morgan AP, Takeda K, et al. Wild mouse gut microbiota promotes host fitness and improves disease resistance. Cell. 2017;171(5):1015-28.

73. Kedzierska K, Valkenburg SA, Doherty PC, Davenport MP, Venturi V. Use it or lose it: establishment and persistence of T cell memory. Front Immunol. 2012;3:357.
Ready to submit your research? Choose BMC and benefit from:

- fast, convenient online submission

- thorough peer review by experienced researchers in your field

- rapid publication on acceptance

- support for research data, including large and complex data types

- gold Open Access which fosters wider collaboration and increased citations

- maximum visibility for your research: over $100 \mathrm{M}$ website views per year

At BMC, research is always in progress.

Learn more biomedcentral.com/submissions 